\title{
PRICE DISCRIMINATION AS TREATED IN THE ATTORNEY GENERAL'S REPORT
}

\section{A. Adelman $t$}

One may safely say of the Attorney General's National Committee To Study the Antitrust Laws, as of similar bodies, that whether or not it added to the common weal, it enriched the education of its members. So far as concerns the writer's ideas on the economic nature of price discrimination, he must indeed confess either an enviable consistency or a regrettable inability to learn. ${ }^{1}$ But as a problem in communication between lawyers and economists, where the gaps in understanding still yawn wide; in the relationship of the specialist with the policy maker on one side and with his conscience on the other; and in the resolution of conflict and the imperfect nature of the tool of language-the proceedings of the Committee, in plenary session, in work groups, and in those darker corners where the members were sent whom the Co-Chairmen "ad hoc'd," were richly rewarding.

However, the purpose of this article is not autobiographical. Nor is it in any sense an authoritative exposition of a document which, if it is worth anything, must speak for itself. It may be that in the future, litigants will search for the "intent" of the Committee's draftsmen as today they search for legislative "intent" or as the Roman soothsayers sought knowledge by poking around in the entrails of a goose. One can only take refuge in the common sense observation that probably no two members of the Committee had precisely the same thing in mind when they approved, or disapproved, any given part of its Report. ${ }^{2}$ This article assumes a knowledge of those parts of the Report which deal with price discrimination ${ }^{3}$ and attempts to explain one member's views in somewhat greater detail.

$\dagger$ Associate Professor of Economics, Massachusetts Institute of Technology. Member, Attorney General's National Committee To Study the Antitrust Laws. B.S.S., College of the City of New York, 1938; Ph.D. (Econ.), Harvard, 1948.

1. Most of the ideas stated in this article, sometimes in rather summary fashion, have been developed in more detail in earlier writings. See Adelman, The Consistency of the Robinson-Patman Act, 6 STAN. L. REv. 3 (1953); Adelman, Integration and Anti-trust Policy, 63 Harv. L. Rev. 27 (1949); Adelman, Effective Competition and the Antitrust Lazes, 61 Harv. L. Rev. 1289 (1948); Dunn \& Van Cise, How to Comply witr taE ANTItrust Laws 290, 294 (1954). Detailed references to them will not be made.

2. Report of the Attorney General's National Committee To Study the ANTITRUST LAws (1955) (hereinafter cited as REPORT).

3. REPORT at $155-221$. 
A great and much-abused economist once said of his chief work:

"The ideas which are here expressed so laboriously are extremely simple and should be obvious. The difficulty lies, not in the new ideas, but in escaping from the old ones, which ramify, for those brought up as most of us have been, into every corner of our minds." 4

If the reader, while following the economic exposition, is willing to put out of his mind, for the time being, any possible legal implications, he will find no difficulties in it. Such a purely economic analysis is needed because the Report does not undertake it. There is, to be sure, a chapter on Economic Indicia ${ }^{5}$ which, I should like to think, will be helpful to legislature, bench and bar, but this does not pretend to be more than a selection of certain ideas which may be of use in evaluating given cases. The reader may well be puzzled by the fact that price discrimination is discussed so differently under Economic Indicia and under Distribution, ${ }^{6}$ and wonder whether at both places the Report is talking about the same thing. I think it is, but it seems worth the effort to try building a bridge between them.

I.

Price discrimination, in the economic sense, exists when price differentials do not correspond altogether with cost differentials. Discrimination may exist without any price differences when two, or more, buyers are charged the same price but it costs less to serve one than another. A buyer paying a lower price is discriminated against if the lower price does not fully reflect a lower cost of serving him. The "lower costs" may arise from the omission of certain manufacturing processes, or distributive services, or many other reasons; and, since price less cost equals profit, it follows that price discrimination, in the economic sense, is rigorously defined as a difference in the profit earned from one customer as against another. ${ }^{6 a}$

This condition is of course very widespread in the business world. Most of these profit differentials, which we will henceforth call discriminations, are transitory and fortuitous. If there were established a condition of perfect non-discrimination this morning, by nightfall there would be plenty of discrimination, if for no other reason than unforeseén changes in supply and demand. 'Those changes make some

4. Keynes, The General Theory of Employment, Interest, and Money viii (1936).

5. REPORT at $315-42$.

6. Id. at $129,155-221$.

$\therefore 6 \mathrm{a}$. More precisely, it is the profit rate on the current value of the necessary investment, converted to a per-unit basis. 
customers, some products, some localities, some channels of supply, more remunerative than others, and an alert business management will always be on the lookout for these more profitable opportunities and exploit them as best it can.

But this process must under active competition destroy the discriminations which initiated the process. As business concerns devote their labor and capital to these more profitable sales, and pro tanto withdraw from less profitable ones, they increase supply in the one market and decrease it in the other. So long as there is any profit differential-any discrimination-there remains an incentive to continue the process until the discrimination has been completely removed; but in the meantime, other changes in market conditions have created new differentials. Thus, under competition, discriminations are always being created and always being destroyed. To block either the creative or the destructive part of the process is to block competition.

Under competition, there cannot be any stable and permanent price discrimination on any given product. Price differentials net of cost differentials, i.e., variations in profit per unit as between two or more buyers, cannot be maintained permanently. For under competition, sellers will try to switch from the low-margin to the high-margin buyers until all the margins are equalized and there is no more discrimination. The only genuine exceptions to this rule arise from differences in efficiency and from the ignorance or inertia of buyers or sellers about better alternatives. All other "exceptions" are spurious, and upon examination, turn out to involve cost differentials which merely cannot be precisely measured.

It cannot be emphasized too much that cost differentials in economic language do not mean "cost justification" under the RobinsonPatman Act. ${ }^{7}$ That is an altogether different subject-a statutory standard of proof, not an economic category. We are concerned with cost-price differentials which exist as business facts and which at least a minority of buyers or sellers know to exist, ${ }^{8}$ whether or not they have a precise idea of just how much they amount to. Profit-and-loss statements are "mere estimates," with wide margins of error, and yet they are used as guides to business policy. The reader should be disabused once and for all of the notion that cost differences in the economic sense refer to cost accounting records-still less to that tiny minority of cost accounting records which would pass FTC scrutiny. Capitalist enterprise and profit incentives existed long before cost

7. 49 STAT. 1526 (1936), 15 U.S.C. §13(a) (1952). below.

8. The reason why only a minority need know of the cost difference is explained 
accounting records; and relatively few business decisions are based merely on cost accounting records, useful as these may be. Our experience with price control taught us that much.

If, therefore, stable discrimination on any given product is impossible under active competition, its presence indicates some block somewhere to the competitive process. For example, a monopolist will increase his profits if he is able to divide his customers and get from each of them the highest price each is willing to pay. The current price of refined copper is around 50 cents per pound; but there are customers who if need be could be made to pay ten or a hundred times that much. A monopolist of copper would try to sell to them at the high price if he could prevent those who bought at the lower price from re-selling. What is perhaps not so readily apparent is why our fictitious copper monopolist accepts the lower price from these other customers. The reason is that if he tried to divert copper from the lower-to the higher-paying customers, some of it would remain unsold, because these customers will take no more at the higher price. So we arrive at a general rule: a seller who accepts lower net prices (lower profit per unit) from some buyers than from others does so because he is better off selling some output at the lower margin than if he tried to push it into the higher-margin market; for he could not sell it in the higher-margin market except by lowering the price so far as to reduce his total profits.

Of rather different but perhaps greater significance is stable discrimination practiced by a group of sellers. It can only exist if they have some agreement or understanding to get higher margins from some buyers than from others. The essence of such an understanding is that nobody will undercut the agreed-on price schedule and offer better terms to the higher-margin buyer. If some of the sellers do this, they will begin to attract away this higher-margin trade, and others will jump on the band wagon. Starting perhaps with offers to pass on a fraction of the higher margin, the competitive process would in time erode away all of it. Hence its persistence over time cannot be explained except as resulting from some kind of understanding to inhibit competition. (This is, of course, no necessary proof of illegal behavior.)

The tie between discrimination and monopoly power is often hard for lawyers steeped in Robinson-Patman to accept because discrimination seems to them to be found mostly among small, powerless concerns. $^{9}$ This impression is in large part derived from price "discrimi-

9. See p. 232 infra. 
nation" in the Robinson-Patman sense, not in the economic sense. A firm with a one-price policy may be really discriminating by getting more from some customers than from others. Conversely, the "discriminating" firm may be a non-discriminator, doing no more than bid for the wider-margin business by offering some or all of the margin to gain additional trade- - to the disgust of its fellows.

This deserves a moment of attention. Let the reader consider the very small firm with an infinitesimal share of its market, for example, the grain farmer. On anybody's definition, such a firm has no power or "bargaining power" whatsoever. Yet nobody ever heard of it discriminating in price. A reasonable farmer has no need to shade the price to anyone, since he can sell all he desires to sell at the current price. Nor can he hope to get more than this price from anyone, since a customer has plenty of other suppliers from whom to buy. He cannot, therefore, discriminate in price; any differential he grants is and must be merely an allowance for lower quality, or freight or other service performed.

As we get farther away from these markets, the possibility of discrimination, by small sellers with little market power, does arisefor a rather special, but often important, reason. A small seller, let us suppose, is practicing genuine price discrimination-taking larger net returns from some customers than from others. Obviously, he must be better off doing it than trying to sell everything at the higher price. Now a monopolist, as already seen, knows that he has sold all that the higher-margin market will absorb at the existing price and that he is better off dumping the excess at the lower price than bringing down the price in the other markets. If the small seller does not attempt to sell everything at the higher price, it follows that there is some inhibition on his freedom of action. If he passes up the apparent chance to take a higher profit, it is because he is convinced that the sellers as a group are better off trying to get the higher price on smaller sales and disposing of the excess to some more favored customers.

When a seller thinks and acts in terms of industry welfare as a whole, he is of course thinking and acting precisely as would a monopolist, who is the industry as a whole. Hence the small seller who follows a consistent and stable pattern of price discrimination in the economic sense, not Robinson-Patman "discrimination," is adhering to an industry-wide understanding-which need not be an agreement or conspiracy in the legal sense. It may be a time honored custom; followed by all because it increases profit; or it may result from informal pressure by others. 
So far it looks as though discrimination, except when unintended or "passive" discrimination, ${ }^{10}$ is always evidence of monopoly behavior. However, this is not so. For, when a non-competitive price is being maintained at a higher level, and a seller wants more volume, the temptation is great to reduce the price to some buyers for the sake of the additional sales volume and larger total profits. Under these circumstances, discriminatory selling may be evidence not of a functioning monopoly but of an ineffective or disintegrating one.

This leads us to a paradox which is of great practical importance. Let us imagine a group of sellers who charge discriminatory prices to several classes of buyers. One seller wants to shade prices for more volume, and he therefore offers a better deal to some buyers. It is quite likely that his offer is simply the recognition of lower costs of serving those buyers, i.e., the recognition of higher margins per unit. Now his price cut may be discriminatory in either or both of two senses: he is not lowering his prices to all buyers; and the new lower prices may not be offered to all of the lower-cost (wider-margin) buyers. But his new price structure is yet less discriminatory than the old price structure, in that some of the discrimination has been eroded away through the constant tendency to seek out the wider-margin business. A discriminatory method leads to a less discriminatory result.

Thus general or theoretical reasoning would lead us to expect just the sort of complex situations we meet in real life, where discrimination and non-discrimination are mingled; where some discriminations may indicate control of the market and others, the breakdown of control; where a given price change may in part be discriminatory and in part non-discriminatory. It is perhaps disorderly, but that is the kind of economic system we have, and that is why we need an analytic apparatus to understand it.

\section{II.}

Thus far, we have dealt with price discrimination only as an indicator of price competition failing to operate-or, sometimes, operating after a lag in time. This is perhaps its most important aspect, to flag situations which require explanation. When business concerns accept permanently lower returns from some customers than from others, it is a case of water flowing up hill. The situation may be trivial, or actually desirable, or it may indicate an overdue corrective action, or it may indicate control of the market; and even when it signals control, that may be no violation of law. But signal something it does.

10. For this useful term, I am indebted to my student Benjamin L. Stevens. 
Why, however, should there be any objection to discrimination as such? To the extent that economics has developed a science of welfare, there is no disagreement that passive discrimination resulting from nothing more than pursuit of opportunities as they arise is positively beneficial; and that corrective discrimination, which serves to break down a non-competitive price system, which may itself be discriminatory, is at least useful. Why should there be any objection to stable and permanent discrimination, however? So far as concerns discrimination among ultimate consumers, the answer is by no means clear. Discrimination makes the distribution of real income different from what it would be under competition; but it is difficult to prove that this latter distribution is "optimal" in any rigorous sense. Perhaps we need nothing so refined, but merely a sense of injustice that some people are getting more than others despite their rendering no additional service, either of their own efforts or their own property, that anyone can see. In any case, the problem is of no legal importance.

Discrimination among business concerns, however, is more clearly objectionable, if and only if, competition is needed as the great selective agent of our economy. If we desire the competitive process to insure that only the most efficient processes and producers survive, then discrimination serves to distort the system of rewards and punishments of a profit-and-loss system: it means that the survivors will not necessarily be the most efficient. Before going into the matter a little more deeply, it is worth remarking that for those to whom competition means some more lofty goal than efficiency-say the social and political benefits, so well exemplified in contemporary France, of keeping as many small businessmen in existence as possible-there is no such basic objection to discrimination. In fact, those to whom "competition" means "many happy little competitors" must support discrimination in favor of their proteges and against others, and in fact they do. Witness the Robinson-Patman Act as currently interpreted.

Resuming the economic objections to discrimination: it may prevent the race from going to the swift, either among the sellers who discriminate, or among their customers. We consider each in turn.

\section{Sellers}

Among the sellers themselves, the objectionable situation is predatory or destructive discrimination. The essential need is for the attacking firm to have an outside source of income or a war chest, and for the attacked firm to have no or few other means of sales and profits 
except in the area where discriminatory price cuts are made. Hence the attacking firm, by making deep price cuts in one locality, or on one product line, can trade losses dollar for dollar with the small one until the latter is either put out of business or agrees to follow a policy congenial to the larger firm.

Another essential condition is that entry into the market be difficult. If it is easy, then any attempt of the successful attacker to reap his ill-gotten gains by raising prices or deteriorating service would mean simply a loss of trade.

A milder form of this conduct, not predatory but still preclusive and uneconomic, was well exemplified in the Shoe Machinery case. ${ }^{11}$ The district court stated with emphasis that United did not try to kill off competition when it set its leases to yield widely varying rates of return on the applicable investment. But ". . . in the face of competition, and with the purpose of meeting or defeating that competition, and retaining or expanding its own share of the market . . .," United lowered prices or improved quality to ". . . reach only that area of the shoe machinery industry which [was] being assailed by a competitor. . . ."12 Thus their discrimination was both an important indicator of their monopoly and an important aid to maintaining it; both cause and effect. A highly sophisticated district court recognized that price discrimination might be justifiable or actually desirable in certain situations, but that the case at bar fitted none of them.

This portion of the opinion has been called "one of the most disturbing rulings in recent years." ${ }^{\text {is }}$ It does not seem an over-subtle distinction to say that this part of the opinion was not a ruling but a finding of fact, and, in my own view, a correct one. United's price discrimination was not held an independent ground for liability, but rather an important piece of evidence to show United's monopoly power, in the economic sense. This power, plus something more, constituted "monopolization" in violation of section 2 of the Sherman Act. Consistent with our interpretation of this part of the opinion as finding rather than ruling is the district court's explicit refusal to consider putting non-discrimination into its remedial decree.

What may be "disturbing" about the ruling is simply its possible misunderstanding and misuse. It is an easy if illicit step to say that any company, preferably large, is probably monopolizing by taking different rates of profit on different lines of business; and the argu-

11. United States v. United Shoe Machinery Corp., 110 F. Supp. 295, 326-29, 340 (D. Mass. 1953), aff'd, 347 U.S. 521 (1954).

12. Id. at 329.

13. Van Cise, Understanding the Antitrust Laws 104-05 (1955). 
ment has been made that there is a tendency for a large, diversified firm to take on business at prices which do not cover full costs, thereby thwarting competitors who might really be more efficient. This supposed tendency does not exist. Of course a diversified firm may be "passively" discriminating by doing the best it can in several markets of unequal competitive intensity but in none of which it has any substantial monopoly power. However, the large diversified firm is no more or less willing than any other firm to take permanently thin or zero margins over cost. Like any other firm, it may do so in the hope that demand will revive and prices improve; or it may be stuck with an operation out of which it will try to take as much of the investment as it can, and then get out. There is no rhyme or reason in such behavior as a permanent matter, except by a monopolist who is able but unwilling to switch from the lower- to the higher-profit market because he would flood the latter, bring down the price and reduce his total profit. This requires corroborating evidence, which was of course present in Shoe Machinery, but cannot be assumed into existence.

The economic analysis of injury to competition among sellers by price discrimination really reduces to the traditional legal query: would a reasonable and prudent business manager find it in his interest to perform these allegedly predatory or preclusive acts? Unless the evidence permits us to answer Yes, the inquiry should stop right there.

\section{Buyers}

We turn now to injury to competition among buyers through price discrimination, and on the whole this is in economics a simpler matter. The buyer whose purchases yield the seller the lower margin of profit (although this does not mean necessarily that he is receiving the "lower price" in the world of Robinson-Patman) has an advantage over other buyers not due to his. superior efficiency. The selective force of competition, which would preserve the more and weed out the less efficient is lost or distorted. There may of course be some offsetting gain. A buyer may precipitate a general price reduction, undermining the sellers' stable understanding on prices, by offering additional business at less than the prevailing price to several sellers, who yield to temptation severally and lose their mutual confidence. ${ }^{13 \mathrm{a}}$ When, as explained earlier, a discriminatory reduction serves to change the

13a. The willingness of sellers to accept additional business at a low margin of profit is discussed at p. 227 supra. See also Adelman, Effective Competition and the Antitrust Laws, 61 HARv. L. Rev. 1289, 1330-32 (1948). 
whole price structure in the direction of non-discrimination, this seems like an obvious help to the competitive process. ${ }^{13^{b}}$ Even when the discriminatory reduction does not have an ultimate non-discriminatory effect, the policing power of such buyers to prevent and break up non-competitive pricing is certainly a policing force toward more competition. Of course, there is such a thing as overpaying the policeman, but little can be said about it in general. Appraisals must be in terms of striking a balance of effects in particular markets.

\section{III.}

The Committee's use of a Sherman Act case ${ }^{14}$ rather than a Robinson-Patman case to illustrate price discrimination in the economic sense was not accidental. Whereas, on the whole, Sherman Act cases ${ }^{15}$ involving this phenomenon have adhered fairly closely to economic concepts, such is not the situation when we enter the altogether different world of Robinson-Patman. The $A \& P$ case ${ }^{16}$ was, in $\mathrm{H}$. Thomas Austern's phrase, "a Robinson-Patman wolf in Sherman Act clothing," and illustrates the confusion of economic concepts surrounding Robinson-Patman. The act is generally considered to be directed against price "discrimination" by sellers coerced or influenced by the "power" or "bargaining power" or "coercive power," or something, of large buyers. Now if "power" means monopoly power or market control in the economic sense, it must be said at once that there is no logical foundation for this. There is simply no way discovered by economic analysis to make the connection between monopoly power on the buying side to price discrimination on the selling side. A monopoly buyer, or monopsonist, might indeed pay a single very low price; or he might discriminate in the prices he paid, making separate bargains with his suppliers, and paying some of them more than others. But he could not get sellers to discriminate in price unless the sellers themselves had some monopoly power. As we noted earlier, a seller with zero monopoly power (pure competition) would never have the motive or

13b. Id. at 1331-32 \& n.167.

14. United States v. United Shoe Machinery Corp., 110 F. Supp. 295 (D. Mass. 1953), aff'd, 347 U.S. 521 (1954).

15. The lawyer is fortunate indeed to have three such outstanding opinions as Shoe Machinery; United States v. Sugar Institute, 15 F. Supp. 817 (S.D.N.Y. 1934), aff'd, 297 U.S. 553 (1936) ; and United States v. Corn Products Refining Co., 234 Fed. 964 (S.D.N.Y. 1916). It is a fair generalization that the courts analyzed discrimination, found it to be symptomatic of control of the particular market, and decided accordingly.

16. United States v. New York Great Atlantic \& Pacific Tea Co., 173 F.2d 79 (7th Cir. 1949). 
the power to discriminate in price. A seller who was only a small part of the market would not charge a lower price to the big buyer; he would sell all he could to the better-paying buyers. If all sellers did this, the final result would be to equalize the price paid by the large semi-monopolist buyer with the prices paid by others. This less than competitive price might of course be as objectionable as a higher than competitive price, but it would not be discriminatory.

Buying power or "bargaining power" of buyers leading to price discrimination by sellers is therefore like the Emperor's new clothes; one's professional duty is to say that there is no such thing. The residuum of sense in the idea is that sellers with some appreciable market control are able to charge higher prices to smaller buyers who cannot shop around than to large buyers who can. In other words, the monopoly power of certain sellers is limited by buyers who lack any monopoly buying power but who do enjoy an economy of larger size - the ability to maintain a buying organization.

There is a widespread impression that the Chain Store Investigation of the Federal Trade Commission disclosed much price discrimination in favor of large buyers by small suppliers with little bargaining power. The Investigation established no such thing. It estimated that roughly 85 per cent of the differences in selling price between chain and non-chain stores was accounted for by lower operating costs. ${ }^{17}$ Even this was a gross underestimate because the Commission made little or no allowance for cost differentials. The FTC made no attempt to find out whether and to what extent quantity discounts corresponded to cost savings; they considered as "preferential" the granting of the wholesaler's discount to a chain store, even though the latter's warehouse was physically and economically indistinguishable from a wholesaler's warehouse, and sales to it netted the seller no less and probably more. Again, the equivalent of brokerage allowed the buyer was counted as "preferential," even though there was no reason given for supposing that the seller netted any less in allowing the brokerage equivalent to a buyer than to a broker.

As a matter of fact, the economist in charge of the Investigation wrote elsewhere that quantity and related discounts usually failed to make full allowance for cost savings-which means that even before Robinson-Patman there was some discrimination, in the economic sense, against the "preferred" buyers. ${ }^{18}$ Another FTC study showed that in

17. FTC, Final Report on the Chain Store Investigation 55 (1934). (1937).

18. Stevens, An Interpretation of the Robinson-Patman Act, 2 J. MARKET. 44 
1936, the net return to the sellers of fresh fruit and vegetables was greatest on sales to the chain stores. ${ }^{19}$

It is perfectly clear that the FTC was investigating not price discrimination, in the economic sense, but price differentials. To be sure, there was occasional recognition that differentials might do no more than reflect differences in cost, but this was never carried into practice.

What is true of the FTC report is even more obvious in the congressional hearings on the Robinson-Patman Act. ${ }^{20}$ (As for the floor debates, the less said the better.) Now, the fact that Congress plainly was not directing its legislation against price discrimination in the economic sense does not necessarily mean that it was legislating badly. There may have been the best of reasons why Congress should legislate against price differentials rather than price discrimination. But there is no evidence whatever that Congress was ever made aware of the distinction, or realized the consequences, to be explored later, ${ }^{21}$ of their act. There is no way of telling whether they thought they were legislating against price discrimination, or whether they were trying to prescribe discrimination against lower-cost buyers by prescribing price uniformity. Doubtless some knew what they were doing; obviously most did not.

This is rather curious. No brief or opinion in a Robinson-Patman case is complete without great argument about the act and about the legislative intent behind it. Any self-respecting law firm has reams of memoranda on the subject. Yet if ever there were a perfect example of the legislature not knowing the consequences of its actions, and not knowing what it intended, this was it.

"[W]hen a Legislature has had a real intention, one way or another, on a point, it is not one in a hundred times that any doubt arises as to what its intention was. . . . The fact is that the difficulties of so-called interpretation arise when the Legislature has had no meaning at all; when the question which is raised on the statute never occurred to it. . . ." 22

IV.

In order to understand the meaning of the act against price differentials, not against discrimination in the economic sense, let us

19. FTC, 1 Report on Distribution Methods and Costs 140-41 (1944).

20. Hearings Before the Special Committee of the Honse on Investigation of the American Retail Federation, 74th Cong., 1st Sess. (1936); Hearings Before the Committee on the Judiciary of the House to Amend the Clayton Act, 74th Cong., 1st Sess. (1936).

21. See pp. 234-36, 241 infra.

22. Gray, The Nature and Sources of the Law 172-73 (1909). 
imagine a group of sellers who discriminate in that they make more money from certain customers whom they charge the same price but whom it costs less to serve. This is what the act requires. Under competition, as we saw earlier, there would be a strong tendency for the sellers to bid this higher-margin business away from each other, forcing down the margin toward equality with the other customers. This tendency would not require that any sellers know their expenses with cost-accounting precision. It would require only that some sellers know, approximately, that certain classes of sales were more remunerative than others. Once the minority knew this, and acted as it would be in their interest to do, the rest would be forced to follow. ${ }^{23}$ (If the minority turned out to be wrong, the rest would not be forced to follow.) That is how the competitive process operates. Now, if the sellers wanted to temper the competitive wind to the shorn wolf, they would enter into an agreement not to reflect the lower costs in lower prices. Then each of them could quote uniform prices despite non-uniform costs, could thereby discriminate against lower-cost customers, and earn higher profits than would be possible under competition-secure in the knowledge that he was not being underbid.

An agreement to supply this security would of course be illegal and would collapse if even a few parties stopped observance. But the Robinson-Patman Act enforces this result with the sanctions of law.

The clearest-cut example is of course the brokerage clause, section 2(c) ${ }^{24}$ A seller who disposes of his goods through brokers and also through direct buyers is not allowed to recognize any cost savings on selling to direct buyers. He may not accept the same net return from both parties. He must charge the direct buyer a phantom brokerage, and put the extra money into his pocket. This means a discrimination against direct buyers, including cooperative buying groups, and a legally privileged status for brokers. An equivalent of the brokerage clause was part of the notorious Sugar Institute code which the courts struck down in the mid 1930 's $;^{25}$ another equivalent is contained in the agreements between advertising agencies and publishers, against which the Department of Justice has recently filed suit. ${ }^{26}$

23. There might be a period of jockeying for position, with price finally converging to a new lower level.

24. 49 Stat. 1527 (1936), 15 U.S.C. §13(c) (1952).

25. United States v. Sugar Institute, 15 F. Supp. 817 (S.D.N.Y. 1934), aff'd, 297 U.S. 553 (1936).

26. United States v. American Ass'n of Advertising Agencies, $\mathrm{CCH}$ Trade Reg. Rep. (10th ed.) $\Uparrow 66175$. 
But section 2(a), ${ }^{27}$ providing for "cost justification," is in practice not very different from section 2 (c). We mentioned earlier that under section 2(c), no costs saved by dealing with the direct buyer will be recognized by the law to "justify" a price differential. But as a practical matter, very few costs saved by dealing with any buyer can ever be recognized and allowed under the act. The expense of assembling cost information is very heavy and ofter prohibitive. Secondly, there are many costs, particularly distribution costs, on which precise information cannot be had because there are common and joint cost elements. Many cost savings which exist and therefore determine business conduct cannot be estimated precisely or documented even though reasonable men would agree that they do exist, and that their magnitude at least falls within certain limits. The Report emphasizes this fact. ${ }^{28}$ However, it has even greater substantive significance than is apparent there. The burden of proof is on the would-be price cutter. Unless he can demonstrate the precise amount of the lower costs, the law will not even recognize their existence. Thus a procedural requirement results in discrimination against lower-cost buyers and higher profit margins taken from them than could exist under competition. Moreover, the Federal Trade Commission has set standards impossible to meet, although matters may be changing in this respect.

Most important of all, every seller knows that every other seller is in the same boat and will find it difficult or impossible to "justify" a lower price. Each seller knows that every rival, if he is to reflect lower costs in lower prices, must run a gauntlet with almost no chance of survival. Hence there is little danger that any other seller will try to bid away this higher-margin business by the offer of a price cut. The effect of everybody's knowing everybody else's intentions not to cut price is precisely the same as if there were a collusive agreement not to cut the price. The knowledge by each seller that his rivals will not depart from price uniformity for fear of the FTC or the trebledamage suit is far better reassurance than a few telephone calls or a conference in the cocktail lounge.

Given all these facts, the businessman who knows that he saves money by dealing with certain customers will try to get the extra profits from them if he can. If he decides to get more of that business than he has, he will not waste his time and money trying to "justify" a lower price; he will simply try by legal or extra-legal means to get it. For example, some sellers may decide that they are better off specializ-

27. 49 STAT. 1526 (1936), 15 U.S.C. \$13(a) (1952).

28. RePORT at $172-74$. 
ing and selling only to the more profitable types of buyers. In that case, they can sell at one price, stay within the law, and yet obtain the wider-margin business.

Whatever the reason, if at least one or a few sellers are able to pass on the savings to their lower-cost customers, and get business away from their rivals, it then becomes possible, under section $2(\mathrm{~b})^{29}$ of the Robinson-Patman Act, for all competing sellers to do so, since they are merely meeting the equally low price of a competitor. Indeed, the competitors may not have much choice in the matter; they may be forced- "coerced"- to meet the price or lose the business.

Hence the real importance of section $2(b)$ is this: it permits cost savings to be passed on, not directly by being "justified" under 2(a), but indirectly, through the need to meet the competition of the first sellers offering the lower prices. This process usually represents the breakdown of a discriminatory structure of uniform prices and nonuniform profit margins. So long as the act prescribes this kind of structure, the force of competition will push against it, and section 2(b) must be, in the economic nature of the case, a means of escape from the difficulties of cost justification. Hence the meeting-competition issue is important and intractable.

This is why the distinction between discrimination in the economic sense and "discrimination" in the Robinson-Patman sense is not a quarrel over words. It involves the whole competitive process, and the whole meaning of the act. To put the burden of proof on the respondent and accept only cost savings provable with some exactness, and to narrow the meeting competition defense, is to make a choice in favor of the present cartel-like results. The effectiveness of the cartelization must not be exaggerated. It is a general rule that diversity of cost structures makes it difficult to arrive at a stable understanding or agreement among competitors, because a price which would best suit the interests of one group will not suit another. The great diversity of marketing structure, which the Attorney-General's Committee emphasizes, ${ }^{30}$ has disruptive effects upon the act, as it must on any cartel-like arrangement, and the disruption leads to outcries for more stringent enforcement.

Whether it is "right" or "wrong" to ignore cost differences, enforce uniform prices and discriminate against lower-cost buyers, is something for every man to answer according to his own predilections; the consequences happen whether we like them or not.

29. 49 StaT. 1526 (1936), 15 U.S.C. \&13(b) (1952).

30. REPORT at 204. 
The Report proposes a liberalization of both sections 2 (a) and 2 (b), but it does not state with any precision just how far this would go. Hence its suggestion is only an alleviation, not a remedy, and leaves a permanent and vexing problem which would disappear or at least wear a very different aspect if "discrimination" in the law were considered as simply discrimination in the economic sense. However, what is possibly more important than any formal action is that the Report will contribute to the gradual realization, by the bar and the tribunals, of how strange a standard it is which simply assumes that price differentials are discriminatory. A striking example is in the recent dismissal of the Automatic Canteen complaint. ${ }^{31}$ The Federal Trade Commission noted that Automatic Canteen paid lower prices, but it also noted (twelve years after the proceedings were initiated!) that:

"Respondent's price was an f.o.b. while the standard price to its competitors was a delivered price.

"Respondent obtained its confection items in plain cartons .while suppliers shipped the same items to competitors in lithographed cartons.

"Respondent obtained a straight price which would reflect the elimination of free deals and the right to make returns of stale and unsaleable merchandise. The price to competitors did not reflect the elimination of these factors.

"It also appears that in dealing with respondents, suppliers achieved some savings in selling expense.

". . [ [There is a] possibility that the prices accorded respondent were not cost justified. But . . . no attempt was made to circumscribe the area in which cost savings would be operative. . . . [T] he prosecution has not established a prima facie case in this record." 32

Of course, this opinion was in a section $2(f)^{33}$ case and decided only that, in view of these facts on cost, a respondent buyer had no reason to know that his prices were not cost justified. This opinion has no direct significance for section 2 (a). What is striking is that, for over twelve years, these obvious sources of cost differentials were officially ignored, but are slowly forcing themselves into the official consciousness.

Perhaps it is now clear, if it was obscure, why the Report is able to take, without contradiction, the positions that: (1) stable and per-

31. Automatic Canteen Co. of America, Dkt. 4933 (mimeo. Jan. 12, 1955) (order dismissing count 2 of complaint).

32. Id. at $\mathrm{p} .3$.

33. 49 Stat. 1527 (1936), 15 U.S.C. §13(f) (1952). 
manent price discrimination in the economic sense is an indicium of market control, and (2) that price "discriminations," under the Robinson-Patman Act, should be permitted under section 2(b) without any limitations as to duration or extent. The idea that this wider interpretation of section $2(\mathrm{~b})$ permits "discrimination" and, hence, the exercise of monopoly power is simply a play on words. Patterns of price "discrimination" in the Robinson-Patman sense tell us nothing about whether or not there is any price discrimination in the economic sense nor hence any reason to suspect market control.

This statement is meant literally and deserves emphasis by way of analogy. Suppose that we wished to inquire whether a corporation was profitable. We would need to know whether the receipts exceeded the outlay, and by how much. The fact that the company had receipts of thus many millions of dollars would be evidence, but not only would it not be conclusive evidence of profitability, standing by itself, it would not even be prima facie evidence. It would support no conclusion, not even the most tentative. Similarly, and for reasons so well illustrated by the quotation from Automatic Canteen, the existence of the most stable and permanent price differentials or Robinson-Patman "discriminations" would not even be prima facie evidence of discrimination in the economic sense, or evidence of a block to competition or the exercise of monopoly power.

\section{$\mathrm{V}$.}

On the optimistic or, if one likes, pessimistic assumption that the recommendations of the Committee will be largely carried out, it seems worth while to look briefly at the type of price discrimination case which will assume greater importance. It is a type which has emerged most clearly perhaps in the so-called "area price discrimination" cases, but this is largely fortuitous. Substitute "product" or "distribution channel" for "area," and the problems of economic analysis and public policy are the same.

The Report ${ }^{34}$ refers briefly to the General Foods decision. ${ }^{35}$ Nearly all members approved it as a "sound and accurate reading" 36 of the law, on the point that a mere difference in price was not presumptively illegal and that in all cases "the substantiality of the effects reasonably probable" ${ }^{37}$ had to be established. Apart from this point, the agreement would have been much less wide, and indeed there is no

34. REPORT at 162-63.

35. General Foods Co., Dkt. 5675 (mimeo. April 27, 1954).

36. REPORT at 163.

37. Ibid. 
way of knowing which way the majority of the Committee would have inclined, had there been any need to comment further on General Foods. The writer. who concurs in the Report on this point, considers the decision as otherwise a regrettable one, and believes he would not lack company from his colleagues. The reasons are of a fairly general order.

The acts of General Foods were discriminatory in the economic sense; there was no way of accounting for the price differences by cost differences-quite apart from any possibility of cost "justification." Furthermore, this discriminatory pricing was not an incident of competition, where the company granting the differential was one of a number of producers, engaged in a brisk oligopoly struggle for business. Here, on the contrary, General Foods was close to being a national monopolist. The origin of the near-monopoly was a lawful one (a patent), but its maintenance by means of price discrimination, after the expiration of the patent, might raise questions under sections 1 and 2 of the Sherman Act. ${ }^{88}$ This aspect is sharpened by certain correspondence which suggests, although it does not prove, specific intent to eliminate a competitor..$^{39}$ Even if this document be disregarded or its implications rebutted, the least that can be said is that General Foods was confronted with a localized threat to its dominant market position and was able to cut prices in only one part of the country while maintaining prices everywhere else. This was not an instance of "passive discrimination," or of a seller under strong though imperfect and unequal competitive pressures. It was entirely unlike the situation in the $A \& P$ case, where the defendant sold at varying profit margins in many markets, in none of which it had monopoly power. ${ }^{40}$

What should be, and what is, the applicable law to such situations? Part of the answer must be candidly to admit that under the present law, the problem is insoluble as a general problem. Escape must be found in every instance through the facts of the particular case, so that one can say that antitrust objectives are better served by finding for one party rather than the other. But in every instance we are faced by the dilemma: to forbid discriminatory pricing is to freeze the pres-

38. Cf. United States v. United Shoe Machinery Corp., 110 F. Supp. 295, 342-43 (D. Mass. 1953).

39. General Foods Co., Dkt. 5675, at 8 (mimeo. April 27, 1954) (dissenting opinion, quoting Commission exhibit 28).

40. United States v. New York Great Atlantic \& Pacific Tea Co., 173 F.2d 79 (7th Cir. 1949); cf. United States v. New York Great Atlantic \& Pacific Tea Co., Civil No. 52-139, S.D.N.Y., Jan. 18, 1954 (final judgment), where the mere existence of differential profit margins is agreed not to constitute liability. Nothing more was ever proved in the criminal action. 
ent price pattern, to put an obstacle in the way of adjustment of prices to changes in supply and demand, and to give the local producer a kind of tariff protection. The realization of this fact lies not too far below everyone's consciousness. As a very amateur student of advocacy, the writer could not help but be struck by the way the Brief for $R e$ spondent, in its very first sentence, hit the keynote that the western competitor of General Foods was in search of a regional monopoly and that any cease-and-desist order would help him toward it. (It cannot be said that this individual's testimony did much to remove that impression.)

On the other hand, new enterprise should not be discouraged from starting up in areas where the prices of the dominant rivals offer the widest margins over the costs of the local producers. By practicing the kind of discrimination exemplified by the acts of General Foods the dominant firm can preclude the existence of equally efficient smaller firms who might indeed become more efficient and in the fullness of time displace the large firm-by the simple expedient of cutting prices to meet the competition.

In attempting, therefore, to find a solution on particular rather than general grounds, and hence avoid, or evade, the central dilemma, one might begin by asking whether General Foods was not liable under the Sherman Act as presently interpreted, rather than the RobinsonPatman Act. This possibility aside, it would seem that the anti-competitive effects of General Foods' action much outweighed the competitive ones. According to the document cited earlier, the small western producer would have been able to expand and take over more and more trade to the east, and would by 1942 have been offering "some pretty tough competition in the middle West" where no competition of any kind had existed before. As against this, the hearing examiner and the Commission appeared impressed by the increase in the absolute volume of sales by the smaller producer, but this is simply a re-statement of the formula, which the Report rejects, that (non-) injury to a competitor is (non-) injury to competition. ${ }^{41}$ Even if we grant what actually seems doubtful, that the western producer should have been deemed non-injured, surely the competitive process was thwarted by General Foods' discrimination. Hence the dissenting opinion of Commissioner Mead, who would have found competitive injury because of changes in the relative position of the respondent and its rivals, seems like much better economics. In view of the Clayton Act forbidding acts "where the tendency may be . . ." 42 
his opinion seems to the writer to be better law. This is of course not to endorse the rest of his opinion, where he purported to prove competitive injury by the opinion testimony of the respondent's competitors. It is detestable to make a man a judge in his own case, and it is nonsense to treat the unsupported opinion of an interested party as though it were a verified fact. However, a good argument is not refuted by a companion bad argument, and the unacceptable parts of the dissenting opinion leave untouched the more convincing ones. Arguments, like men, should not be condemned by their bad associations.

\section{VI.}

I have largely restricted this article to sections $2(a)$ and $2(b)$ of the Robinson-Patman Act, in the belief that these key provisions give us enough for an appraisal of the Report. In summary: the Robinson-Patman Act as now interpreted accomplishes economic discrimination against certain buyers because it does not permit the lower costs of serving them to be taken into consideration. This thwarts the competitive result and builds up pressure for avoidance or evasion. Partial relief from the situation is accomplished if even a few sellers are able to lower prices legally because others are then able to follow suit. The restriction is great, and the exemption is very small-in fact, it has never prevailed in any finally decided order. ${ }^{43}$ The sum and substance of the Report is its suggestion that the restriction be relaxed and the exemption kept at least as wide as it is now. Whether the cost defense can be much widened remains to be seen, perhaps when the report of the Advisory Committee on Cost Justification is completed and made public. Whether section $2(\mathrm{~b})$ can assume any importance in view of the heavy burden of proof it requires, the showing of good faith on the part of the respondent, remains also to be seen. ${ }^{44}$ Since the act both enables and compels businessmen to practice stable and permanent discrimination, a monopolistic practice, its continuance in any form will present vexing problems of reconcilement with the Sherman Act.

This being the case, why not advocate the complete repeal of the Robinson-Patman Act? Let us recall that no respectable findings of fact were ever made that there was much discrimination in favor of any buyers, over and above cost differentials; the widely held belief that this was so is merely an important psychological and political

43. RePort at 205.

44. "Good faith" has nothing to do with anyone's state of mind or subjective intent. It indicates an absence of collusive or predatory behavior. 
fact. The law itself has important anti-competitive consequences, and what is, perhaps, more important than any economic aspect is the tone and the atmosphere of its enforcement. If I were to characterize the attitude of my colleagues toward the Sherman Act in one word, it would be, "respect." One could not make the same statement about the Robinson-Patman Act. It promotes discrimination and thwarts competition while professing to do just the contrary. Edward $\mathrm{H}$. Levi has spoken of ". . . the disease of duplicity with which the Act is infected." ${ }^{45}$ This is harsh language for a law school dean to be using about a statute, and it is widely echoed. Why not then be rid of it? What stands in the way except a craven reluctance to advocate something politically impossible? If the Committee was going to report not what its members believed, but what expediency dictated, why appoint any such Committee in the first place?

For better or worse, the writer was and is unwilling to go so far. One reason may be shown in a comparison with the "fair trade" issue. Here the question is whether permission to fix prices should be inserted into an act against price fixing. "Fair trade" has no other meaning or purpose but to raise prices by joint action above the competitive level. Now, if it were true that the Robinson-Patman Act as currently interpreted, disregarding some significant decisions of the last few years, were the intent of Congress, then the only honest course would be to say, as was said of "fair trade": Congress erred, and should undo its error. But we have already seen that no intent of any kind can logically be imputed to Congress. The statute must be taken to mean what its language says. On its face, it makes it unlawful "to discriminate in price" where the effect may be to lessen competition. We saw earlier that discrimination in the economic sense might be undesirable in itself and indicative of monopoly power. There seems no reason why "discriminate in price" can not be brought close to the economic concept, and the legal interpretation brought close to the norms and standards of the Sherman Act. At least, the attempt could be made. If it is not successful, then the question of repeal will be in order.

45. Symposium, The Robinson-Patman Act-Is It in the Public Interest?, ABA Section of Antitrust Law 60, 67 (1952). 